\title{
Reproductive phenology of Euterpe edulis Mart. in two altitudinal classes in the Brazilian Atlantic forest
}

Euterpe edulis Mart. is an endangered palm tree. This species is of high ecological importance because it produces flowers and fruits in large quantities for pollinators and dispersers. Phenological studies help to understand the periods of availability of these resources, as well as allowing relating the species reproductive cycles with environmental variables such as altitude, precipitation, temperatures and relative humidity. Knowing that altitude influences meteorological variables, this study aimed to follow the reproductive phenology of E. edulis in two altitudinal classes and to verify if there is a difference in the phenological pattern due to the altitudinal difference. The study was conducted in Salto Morato Nature Reserve, a protected area located in the Brazilian Atlantic forest, more specifically, in the city of Guaraqueçaba, Paraná state. Monthly activity and intensity data were collected for the following phenophases: flowering, aborted bunches, immature fruits, green fruits and ripe fruits. Meteorological stations collected hourly temperature and relative humidity data on the altitudinal classes. Meteorological and phenology intensity data were correlated by Spearman correlation. There was a delay in the onset of phenophases in class II (200 to $400 \mathrm{~m}$ a.s.I) compared with class I ( 20 to $100 \mathrm{~m}$ a.s.I). In both altitude classes, ripe fruits were negatively correlated with temperature, indicating that they are available in a period of scarce forest resources. However, the amount of months that ripe fruits were available was different for each altitudinal class. We conclude that altitude influences the reproductive phenology of E. edulis, making this species even more important for feeding the fauna.

Keywords: Altitudinal gradient; Arecaceae; Atlantic forest; Endangered species; Key species.

\section{Fenologia reprodutiva de Euterpe edulis Mart. em duas classes altitudinais na Mata Atlântica brasileira}

\begin{abstract}
Euterpe edulis Mart. é uma palmeira ameaçada de extinção. Esta espécie é de grande importância ecológica, pois produz flores e frutos em grandes quantidades para polinizadores e dispersores. Os estudos fenológicos ajudam a entender os períodos de disponibilidade desses recursos, além de permitir relacionar os ciclos reprodutivos das espécies com variáveis ambientais como altitude, precipitação, temperaturas e umidade relativa do ar. Sabendo que a altitude influencia variáveis meteorológicas, este estudo teve como objetivo acompanhar a fenologia reprodutiva de E. edulis em duas classes altitudinais e verificar se há diferença no padrão fenológico devido à diferença altitudinal. O estudo foi realizado na Reserva Natural Salto Morato, uma área protegida localizada na Mata Atlântica brasileira, mais especificamente, na cidade de Guaraqueçaba, Paraná. Foram coletados dados mensais de atividade e intensidade para as seguintes fenofases: floração, cachos abortados, frutos imaturos, frutos verdes e frutos maduros. Estações meteorológicas coletaram dados de temperatura e umidade relativa por hora nas classes altitudinais. Os dados de intensidade meteorológica e fenológica foram correlacionados pela correlação de Spearman. Houve um atraso no início das fenofases na classe II (200 a 400 m.s.l) em comparação com a classe I (20 a 100 m.s.l). Nas duas classes de altitude, os frutos maduros apresentaram correlação negativa com a temperatura, indicando que estão disponíveis em um período de escassos recursos florestais. No entanto, a quantidade de meses que os frutos maduros estavam disponíveis foi diferente para cada classe altitudinal. Concluímos que a altitude influencia a fenologia reprodutiva de E. edulis, tornando essa espécie ainda mais importante para alimentar a fauna.
\end{abstract}

Palavras-chave: Gradiente altitudinal; Arecaceae; Mata Atlântica; Espécies em perigo; Espécies-chave.

Topic: Ciências Florestais

Reviewed anonymously in the process of blind peer.
Received: 20/02/2020

Approved: 07/03/2020
Andressa Tres (D)

Universidade Federal do Paraná, Brasil http://lattes.cnpq.br/8605526420445542 http://orcid.org/0000-0001-8913-5160 tres.andressa@gmail.com

Alexandre França Tetto Universidade Federal do Paraná, Brasil http://lattes.cnpq.br/7353900312758348 http://orcid.org/0000-0003-2251-964X tetto@ufpr.br

Jaçanan Eloisa de Freitas Milani (iD) Universidade Federal do Mato Grosso, Brasil http://lattes.cnpq.br/1248478849153563 http://orcid.org/0000-0002-4831-2551 jacanan.milani@gmail.com

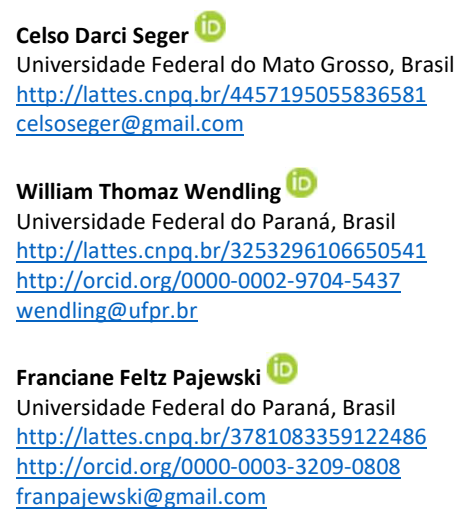

Gabrieli Dickel (iD)

Universidade Federal do Paraná, Brasil http://lattes.cnpq.br/2149817532740128 http://orcid.org/0000-0001-6693-0858 gabrielidickel11@gmail.com
Referencing this:

TRES, A.; TETTO, A. F.; MILANI, J. E. F.; SEGER, C. D.; W. T. W.; PAJEWSKI, F. F.; DICKEL, G.. Reproductive phenology of Euterpe edulis Mart. in two altitudinal classes in the Brazilian Atlantic forest. Revista Ibero Americana de Ciências Ambientais, v.11, n.2, p.23-35, 2020. DOI: http://doi.org/10.6008/CBPC2179-6858.2020.002.0003 


\section{INTRODUCTION}

According to Fritzsons et al. (2016), there is a direct relationship between altitude and temperature in tropical and subtropical regions, where the altitudinal difference interferes in climate, soil and adaptation of existing living beings. On the other hand, even though tropical forest species have their reproduction influenced by local conditions, the species phenology at different altitudes is not fully understood.

Studies on biology, ecology and seed dispersion provide essential information for forest species management and conservation plans (MANTOVANI et al., 2000). Among these studies, phenology is a tool for understanding biological cycles, their causes of occurrence in relation to abiotic and biotic factors, and the interrelationship of such events in one or more species (LIETH, 1974). However, in order to meet future use and conservation expectations, it is necessary to know the resource base offered by these species and forest environments, understanding the seasonality of biological events and their relation to local environmental conditions, such as meteorological and environmental variables.

Euterpe edulis Mart. (Arecaceae) is an endemic palm tree from the Atlantic forest of Brazil. This species has an economic importance, especially for the production of palm heart and the products derived from its fruits. From an ecological point of view, is a key species at the Atlantic forest of Brazil, due to its high fruit production in months when resources derived from other species are scarce in the forests (GALETTI et al., 2013; GARCIA et al., 2016; SILVA et al., 2018). In addition, the production of flowers and fruits facilitates the interaction with the pollinating and dispersing fauna, a common characteristic to many arecaceaes. However, its illegal exploitation and the expansion of livestock contributed to the species become threatened with extinction (BRAZIL, 2014).

Considering E. edulis conservation status, information regarding its ecosystem dynamics and resource availability is important for the management and conservation of the species. From this, the present study aimed to characterize the reproductive phenological pattern of E. edulis, in two classes of altitude, at Salto Morato Nature Reserve in Guaraqueçaba - Brazil.

\section{MATERIALS AND METHODS}

\section{Study area}

Salto Morato Nature Reserve (SMNR) is a protected area located in the municipality of Guaraqueçaba, northern coast of Paraná - Brazil, and comprised between the latitudes -25.135194 S and 25.188083 S and longitudes $-48.270055 \mathrm{~W}$ and $-48.330916 \mathrm{~W}$ (Figure 1). With a total area of 2252.83 ha of Dense Ombrophilous Forest, equivalent to the Atantic forest, SMNR altitudes vary on average from 150 to $400 \mathrm{~m}$, with lower and upper limits equal to 20 and $900 \mathrm{~m}$, respectively (BGF, 2011). SMNR is in the geological domain of crystalline-based rocks (POLIDORO et al., 2002). Dal Pai et al. (2018) identified Cambisols as the predominant soil classification in the reserve.

According to Alvares et al. (2013), the climate in the study region is Cfa. For the Köppen classification, this climate type is a humid subtropical climate with no defined dry season and hot summer, with an average 
temperature of the warmest month greater than or equal to $22^{\circ} \mathrm{C}$. As reported by the reserve management plan (BGF, 2011), the region's rainfall reaches 600 and $800 \mathrm{~mm}$ in the wettest months of the year, and a maximum of $400 \mathrm{~mm}$ in the less rainy months. Relative humidity is on average $85 \%$.

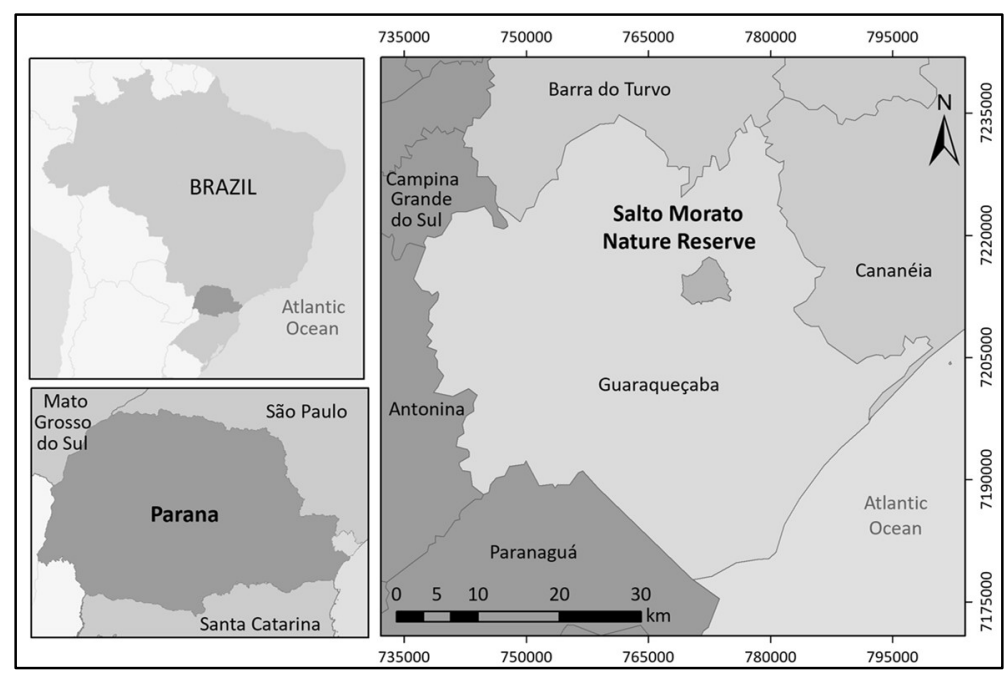

Figure 1: Location of Salto Morato Nature Reserve.

\section{Data collection and statistical analysis}

E. edulis individuals observed during this study are located between altitudes of 20 to $400 \mathrm{~m}$. We defined two altitudinal classes: from 20 to 100 m (class I) and from 200 to 400 m (class II). In each class, we selected nine individuals of $E$. edulis for phenological observation. Given the criteria established by Fournier et al. (1975), this number of individuals is sufficient for phenology studies in tropical species. We collected data monthly, from May 2017 to April 2018. The following reproductive phenophases were observed: flowering; aborted bunches; immature fruits; green fruits; and ripe fruits (Figure 2).

Aborted bunches are bunches that have flourished but not fruited. Immature fruits are small-sized green fruits. Green fruits have their final size, however, still green in color. The ripe fruits are dark purple in color and were considered until their full fall. To observe the phenophases, two analysis methods were applied: the activity index and the Fournier intensity percentage, adapted by Milani (2013). The activity index, proposed by Bencke et al. (2002), indicates the presence or absence of each phenophase in the individual. It is a quantitative method and indicates the percentage of individuals in the population who are manifesting a phenological event at the same time.

The obtained results are used for the classification of synchronization in the population (Table 1). Also, the index reveals the period in which a certain phenophase occurred more generally in the population, allowing a better view of the beginning and end of periods of activity than the intensity index. The calculation of the activity index (Al), presented by Garcia et al. (2016), is given by formula 1.

$$
A I=\frac{I p}{n i} * 100
$$




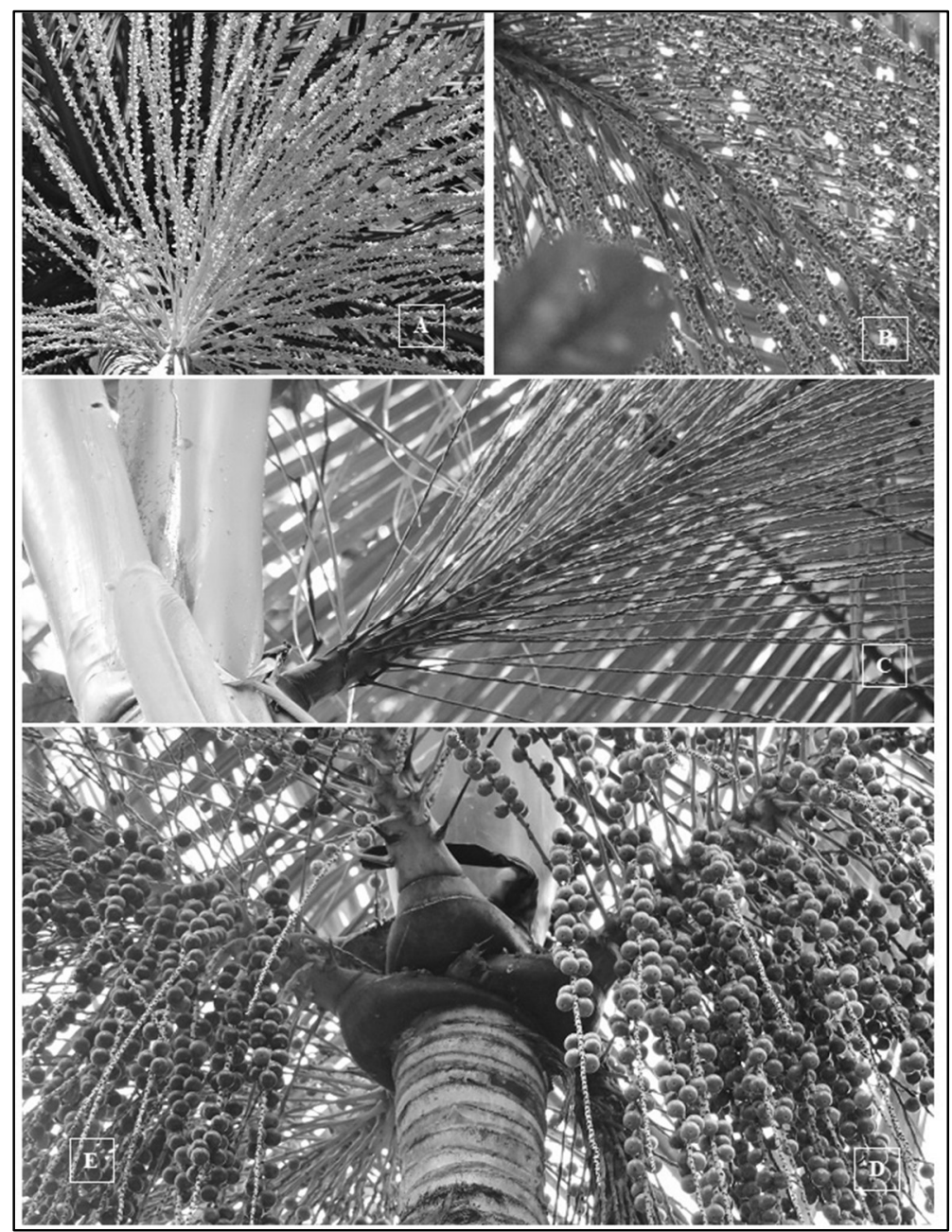

Figure 2: Reproductive phenophases: (A) flowering, (B) immature fruits, (C) aborted bunch, (D) green fruits, (E) ripe fruits.

Table 1: Range of activity index values for determining synchrony.

\begin{tabular}{|l|l|}
\hline Activity index (\%) & Synchrony \\
\hline $\mathrm{Al} \leq 20 \%$ & Asynchrony \\
\hline $20 \%<\mathrm{Al} \leq 60 \%$ & Low synchrony \\
\hline $\mathrm{Al}>60 \%$ & High synchrony \\
\hline
\end{tabular}

In the intensity percentage of Fournier, adapted by Milani (2013), the values are obtained using a semi-quantitative interval scale of four categories (0 to 3), as follows: 0 - absence of the phenophase; 1 phenophase present from 1 to 25\%; 2 - phenophase present from 26\% to 50\%; and 3 - phenophase present above $51 \%$. This method estimates the percentage of each phenophase intensity in the individuals. According to Bencke et al. (2000), the intensity percentage indicates the intensity peaks, which show when a particular phenophase occurs more intensely in the population, and not only the number of individuals who manifested the phenophase, such as the activity index. The population intensity percentage (I) is given by formula 2 .

$$
I=\frac{\sum \text { individual indices }}{n i \times 3} \times 100
$$

Where:

$I=$ population intensity percentage of the phenophase (\%); $\sum$ individual indices $=$ sum of the indices of each individual; $n i=$ total of individuals observed.

We used Oriana 4 software to analyze the period of occurrence, peak, duration, average date and degree of seasonality of each phenophase. The average date is the direction of the arrow in the histogram. 
The degree of seasonality or Length of Mean Vector $(r)$, represented in the histogram by the length of the arrow, indicates that the closer to 1, or the larger the arrow, the greater the seasonality. Rayleigh's test (p) indicates the probability of error.

Weather stations, composed of HOBO H21 data loggers and S-THB sensor, installed in the understory near the individuals, collected temperature and relative humidity data hourly (Figure 3). This sensor has a margin of error of $\pm 0.21^{\circ} \mathrm{C}$ for temperature and $\pm 2.5 \%$ for humidity, based on the manufacturer's instruction manual. We fixed the data loggers and sensors in PVC tubes, $1.20 \mathrm{~m}$ from the ground, as recommended by the World Meteorological Organization (WMO, 2018). Four weather stations were installed in altitude class I and two in altitude class II, based on the distance of $E$. edulis individuals. Thus, the distance between a weather station and $E$. edulis individuals was a maximum of $30 \mathrm{~m}$.

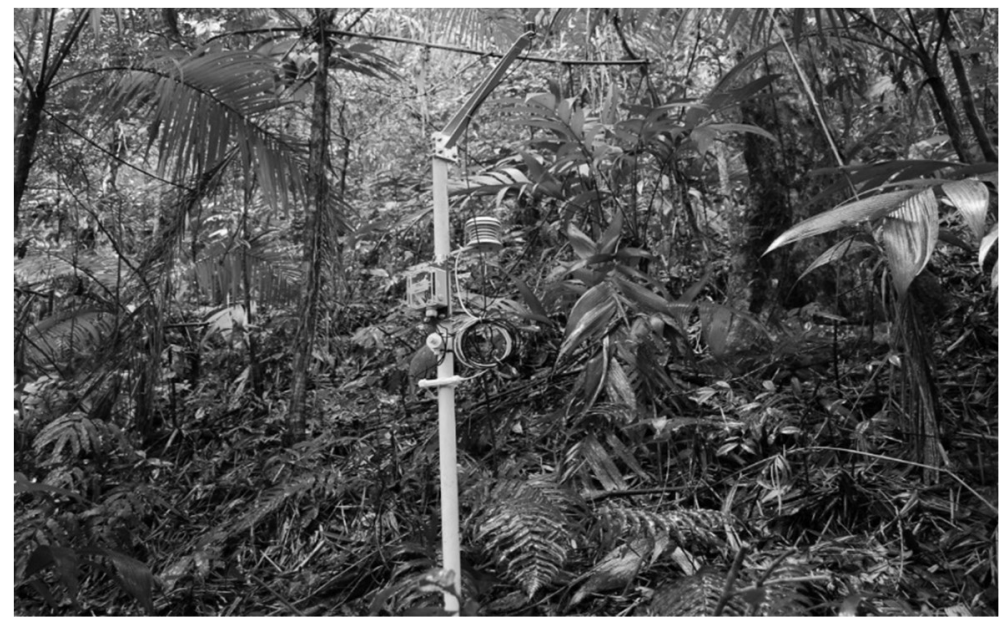

Figure 3: Weather station composed of $\mathrm{HOBO} \mathrm{H} 21$ data logger, installed in the understory, collecting data of temperature $\left({ }^{\circ} \mathrm{C}\right)$ and relative humidity $(\%)$.

We obtained precipitation data from an automatic weather station of the Paraná Meteorological System (SIMEPAR) located within the boundaries of the Salto Morato Nature Reserve (Figure 4). Data were collected hourly throughout the study period and subsequently daily and monthly averages were calculated to correlate with phenological data. Correlation analyses were obtained by the PAST statistical package, applying Spearman correlation, $\mathrm{p}<0.05$.

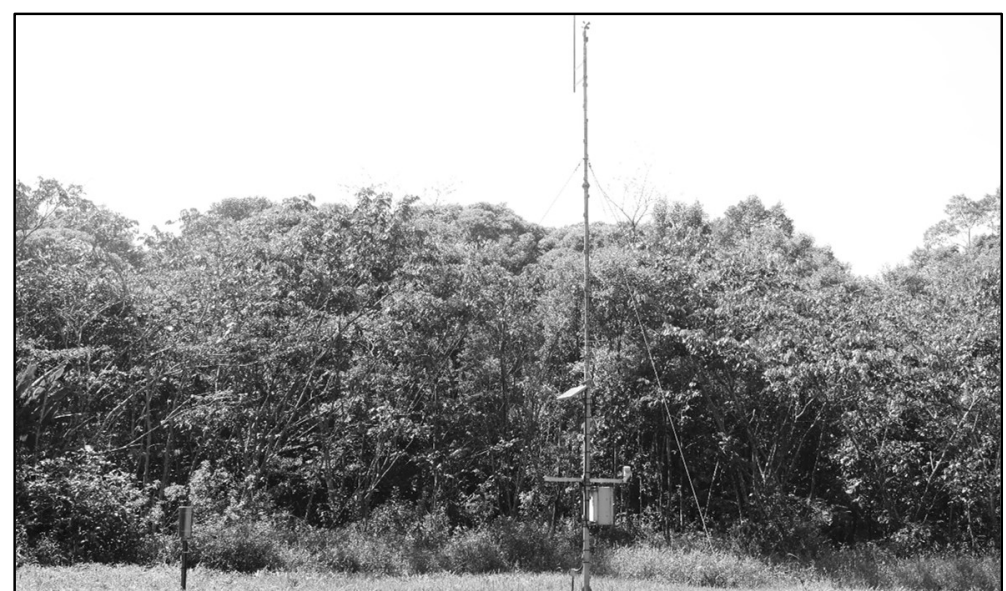

Figure 4: Wheather station of the Paraná Meteorological System (SIMEPAR), collecting the precipitation data used in this study. 


\section{RESULTS}

Activity index

The activity index of the five phenophases observed in the altitudinal classes I and II (Table 2) did not show high synchrony (> $60 \%$ of individuals) in this study.

Table 2: Presence or absence of phenophases in altitudinal classes and values of activity index.

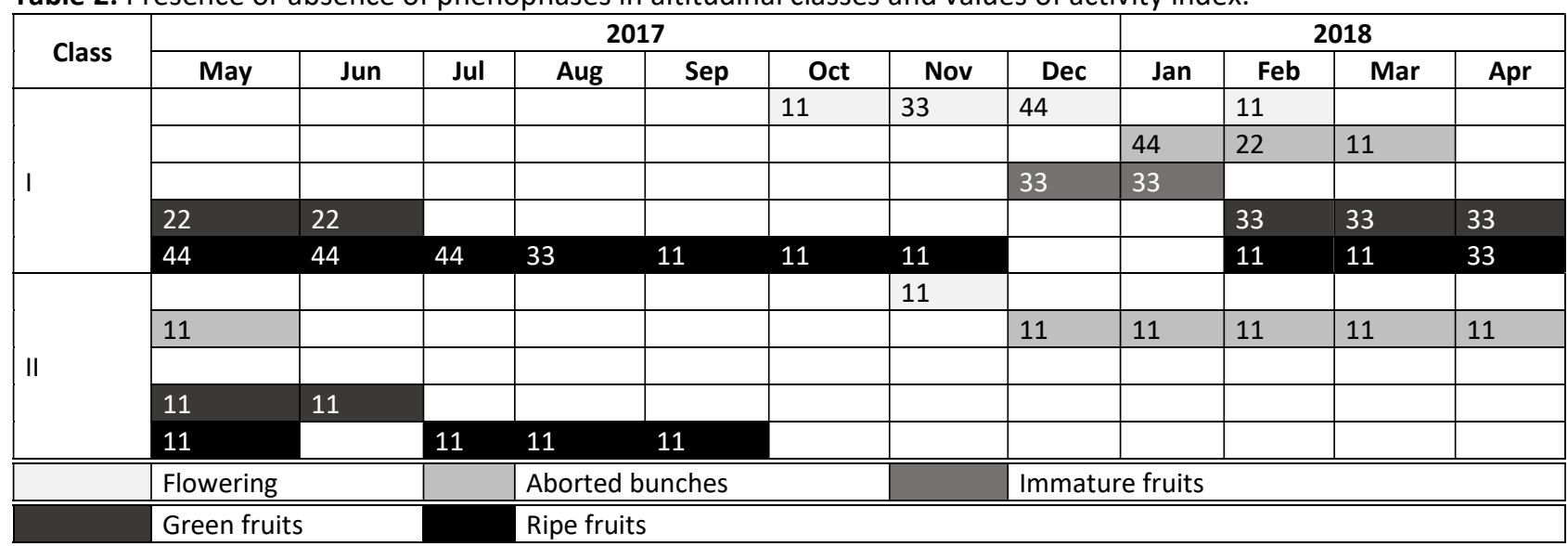

In class I, flowering occurred from October to December and in February. In class II, only one individual presented flowering and one month late compared with class I. Regarding aborted bunches, the highest activity index in class I occurred in January. For class II individuals, the phenophase of aborted bunches was present for six months, but with activity index always asynchronous.

The presence of immature fruits in class I occurred in December 2017 and January 2018, with low synchrony (33\%). In class II, there was no presence of immature fruits throughout the study cycle. Green fruits in class I occurred in the months following immature fruits, with the same low synchrony (33\%). In class II, due to the absence of immature fruits, the subsequent phenophases did not manifest in 2018. However, green fruits were observed in May and June 2017 and ripe fruits in May, July, August and September of the same year, referring to the flowering that occurred in the previous year. Regarding the period of availability of ripe fruits, in the class of lower altitudes ripe fruits were available for 10 months, six more than in class II. This difference could have been slightly smaller if, in the 2018 cycle, flowering of altitude class II had reached fruiting phenophase instead of become an aborted bunch.

\section{Intensity index}

Figure 5 shows the graphs performed with the intensity indices after the circular analysis. Blue polygons represent the intensity index. The direction of the arrow represents the average date and the length of the arrow represents the degree of seasonality. The larger the arrow, the greater the degree of seasonality of the phenophase.

For both class I and class II, the flowering intensity peaks occurred in November, with a percentage of 33\%. For aborted bunches in class II, the same intensity index remained from December/17 until April/18. In class I, the peak of aborted bunches (22\%) occurred in January. As stated earlier, immature fruits of class 
II did not manifest in this cycle. However, in class I, the individuals presented a peak of $33 \%$ in January. After June/17, green fruits from class I were observed again in February/18, with peaks of $33 \%$. Ripe fruits of class I presented intensity peak in July/17 as well as in class II.

\section{Phenophase}

Flowering

Aborted

bunches

Immature

fruits

Green

fruits

\section{Class I}
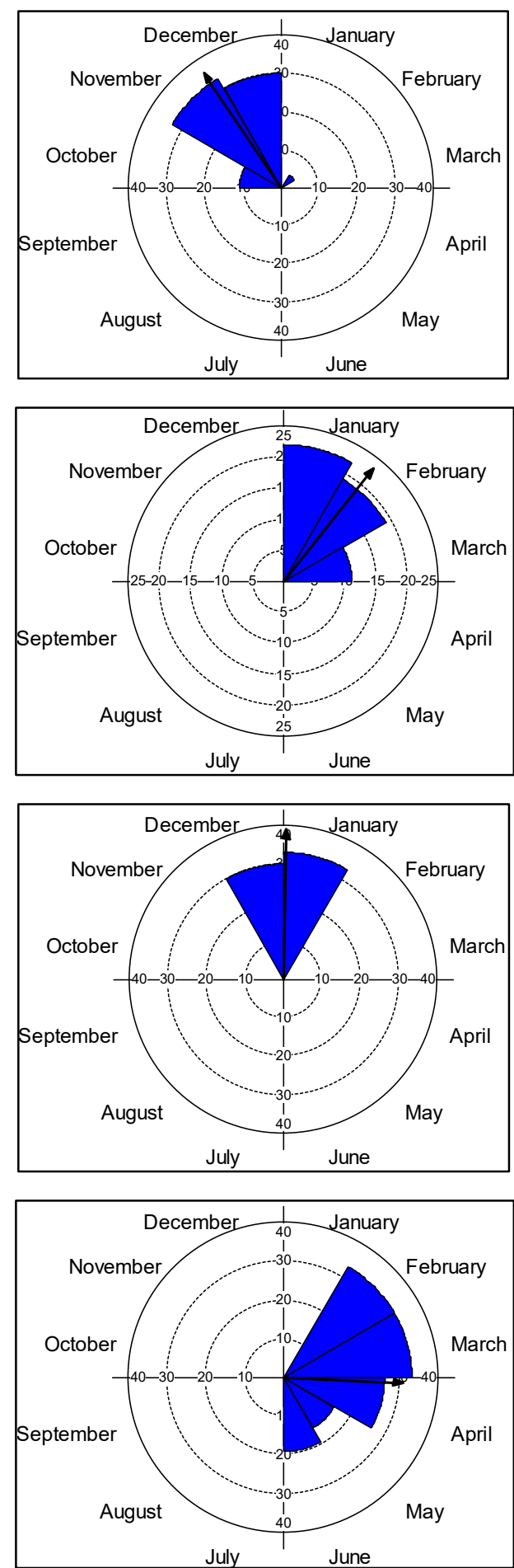

Class II
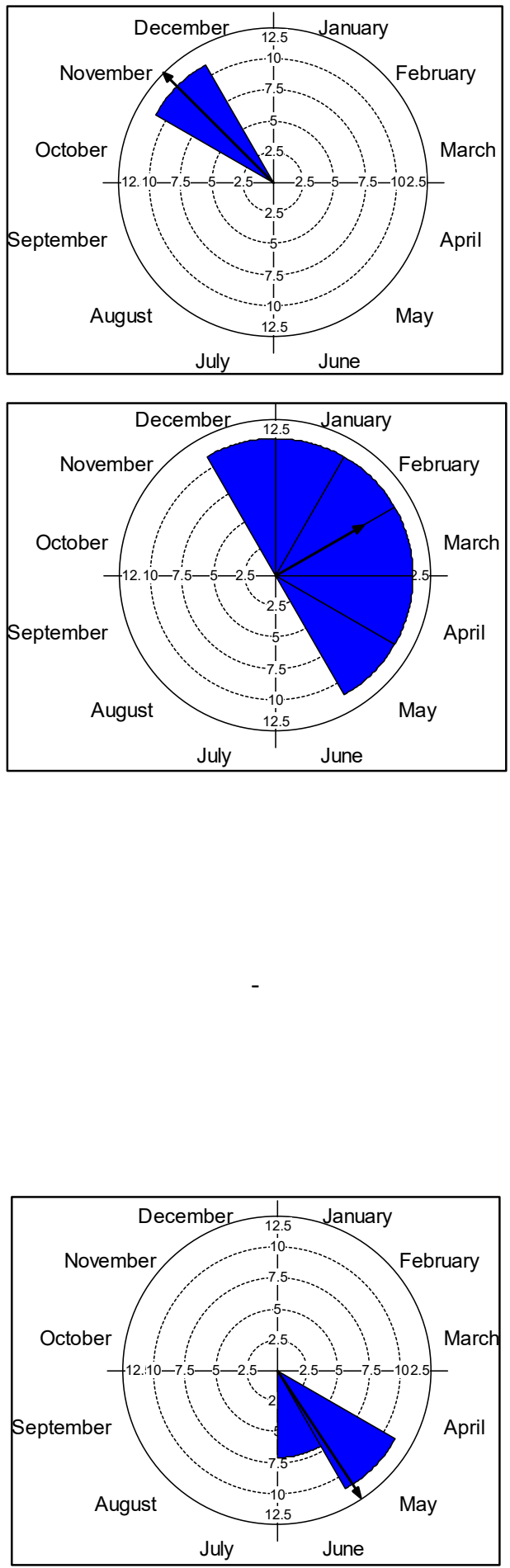

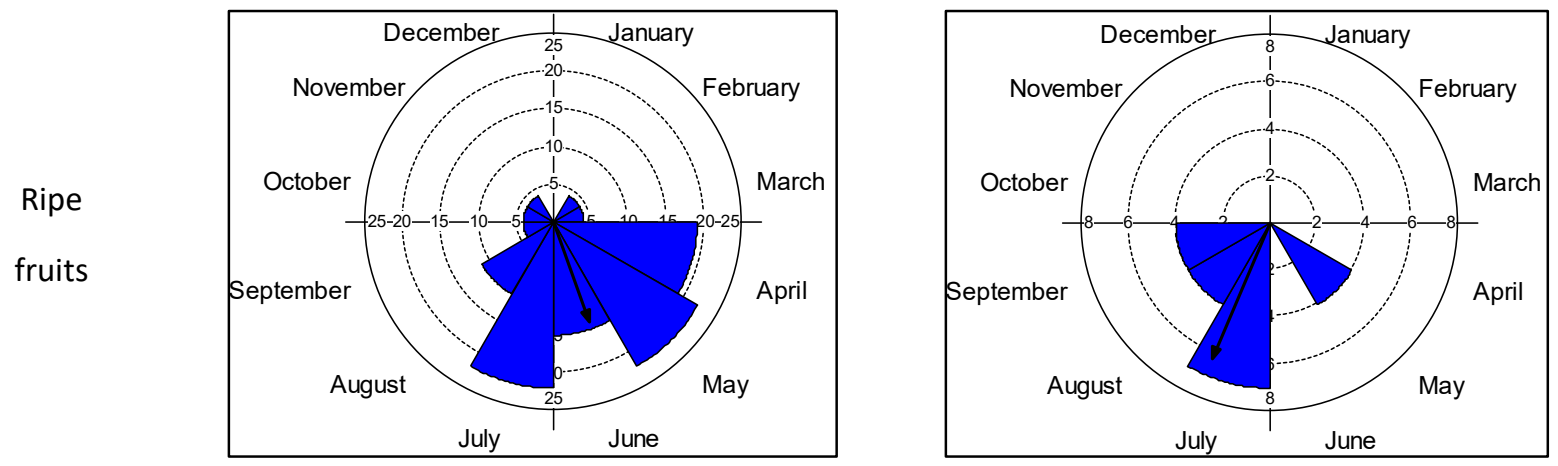

Figure 5: Graphs of circular analysis of the Fournier intensity index.

Table 3 shows that aborted bunches, green fruits and ripe fruits in class I presented both the average angle and the average date of the prior to class II. The flowering phenophase had an opposite behavior, presenting lower average angle and average date in class II. In class I, it is evident that ripe fruits is the least seasonal phenophase.

Table 3: Average angle, average date, degree of seasonality and Rayleigh's test for each phenophase in altitudinal classes I and II.

\begin{tabular}{|c|c|c|c|c|c|c|}
\hline \multirow[t]{2}{*}{ Class } & \multirow[t]{2}{*}{ Variables } & \multicolumn{5}{|c|}{ Phenophases } \\
\hline & & $\mathbf{F I}$ & $\mathbf{A b}$ & If & Gf & Rf \\
\hline \multirow[t]{4}{*}{$\mathrm{I}$} & Average angle (a) & $326.15^{\circ}$ & $38.41^{\circ}$ & $0.73^{\circ}$ & $92.28^{\circ}$ & $160.35^{\circ}$ \\
\hline & Average date & $22 /$ nov & $07 /$ feb & 01/jan & 04/apr & 09/jun \\
\hline & Degree of seasonality $(r)$ & 0.905 & 0.932 & 0.977 & 0.770 & 0.565 \\
\hline & Rayleigh's test $(p)$ & 0.00 & 0.00 & 0,00 & 0.00 & 0.00 \\
\hline \multirow[t]{4}{*}{ II } & Average angle (a) & $315.00^{\circ}$ & $60.00^{\circ}$ & - & $146.59^{\circ}$ & $202.87^{\circ}$ \\
\hline & Average date & $11 /$ nov & $01 /$ mar & - & $26 /$ may & $22 / \mathrm{jul}$ \\
\hline & Degree of seasonality $(r)$ & 1.000 & 0.651 & - & 0.979 & 0.777 \\
\hline & Rayleigh's test (p) & 0.00 & 0.00 & - & 0.00 & 0.00 \\
\hline
\end{tabular}

Note: FI - flowering; Ab-aborted bunches; If - immature fruits; Gf - green fruits; Rf - mature fruits.

\section{Meteorological variables}

The average annual temperature was $20.8^{\circ} \mathrm{C}$ in altitudinal class I and $20.0^{\circ} \mathrm{C}$ in altitudinal class II, with a difference of $0.8^{\circ} \mathrm{C}$ (Table 4). Regarding the monthly average temperatures, the highest occurred in March $\left(23.9^{\circ} \mathrm{C}\right)$ in class I and in January $\left(22.8^{\circ} \mathrm{C}\right)$ in class II. The lowest average temperatures occurred in July for both altitudinal classes. It is possible to observe that temperatures of class II were generally lower than temperatures of class I (values in blue).

Table 4: Temperature $\left({ }^{\circ} \mathrm{C}\right)$ and relative humidity (\%) for altitudinal class I and II.

\begin{tabular}{|c|c|c|c|c|c|c|c|c|c|c|c|c|c|c|}
\hline Class & Variables & May & Jun & Jul & Aug & Sep & Oct & Nov & Dec & Jan & Feb & Mar & Apr & Avg \\
\hline \multirow[t]{4}{*}{ I } & Avg $T$ & 20.0 & 18.0 & 16.4 & 17.4 & 20.3 & 20.7 & 20.7 & 22.6 & 23.6 & 22.8 & 23.9 & 22.5 & 20.8 \\
\hline & Min T & 17.5 & 15.2 & 13.6 & 15.0 & 18.0 & 18.2 & 17.6 & 20.5 & 21.3 & 20.3 & 22.1 & 20.1 & 18.3 \\
\hline & Max T & 23.0 & 20.7 & 19.8 & 20.2 & 23.8 & 24.2 & 24.4 & 25.6 & 26.9 & 25.8 & 26.4 & 25.4 & 23.9 \\
\hline & Avg UR & 97.3 & 99.6 & 99.3 & 98.8 & 98.0 & 97.6 & 96.0 & 98.4 & 98.1 & 98.7 & 99.7 & 99.2 & 98.4 \\
\hline \multirow[t]{4}{*}{ II } & Avg T & 19.0 & 17.5 & 16.5 & 17.0 & 19.4 & 19.9 & 19.9 & 21.7 & 22.8 & 21.9 & 22.7 & 21.4 & 20.0 \\
\hline & Min T & 17.6 & 15.6 & 14.6 & 15.3 & 17.6 & 17.8 & 17.6 & 19.8 & 20.6 & 19.9 & 20.9 & 19.7 & 18.1 \\
\hline & Max T & 20.7 & 19.6 & 18.7 & 19.3 & 22.1 & 22.7 & 22.9 & 24.2 & 25.8 & 24.4 & 25.0 & 23.6 & 22.4 \\
\hline & Avg UR & 98.2 & 94.1 & 94.4 & 94.2 & 96.2 & 94.3 & 93.1 & 97.2 & 95.2 & 96.7 & 98.4 & 96.4 & 95.7 \\
\hline \multirow{4}{*}{$\begin{array}{l}\text { Diff. } \\
\text { II - I }\end{array}$} & Avg T & -1.1 & -0.4 & 0.1 & -0.4 & -0.9 & -0.8 & -0.8 & -1.0 & -0.8 & -1.0 & -1.3 & -1.1 & -0.8 \\
\hline & Min T & 0.1 & 0.5 & 1.0 & 0.3 & -0.4 & -0.4 & 0.0 & -0.7 & -0.7 & -0.4 & -1.1 & -0.4 & -0.2 \\
\hline & Max T & -2.4 & -1.1 & -1.1 & -1.0 & -1.7 & -1.5 & -1.5 & -1.4 & -1.2 & -1.4 & -1.4 & -1.8 & -1.4 \\
\hline & Avg UR & 0.9 & -5.5 & -5.0 & -4.6 & -1.8 & -3.4 & -3.0 & -1.2 & -2.9 & -2.1 & -1.4 & -2.9 & -2.7 \\
\hline
\end{tabular}

Note: Diff. - difference, Avg - average; Min - minimum; Max - maximum. 
The average monthly relative humidity remained above $90 \%$ throughout the study period. However, class I presented higher humidity values than those of altitude class II, with the exception of January.

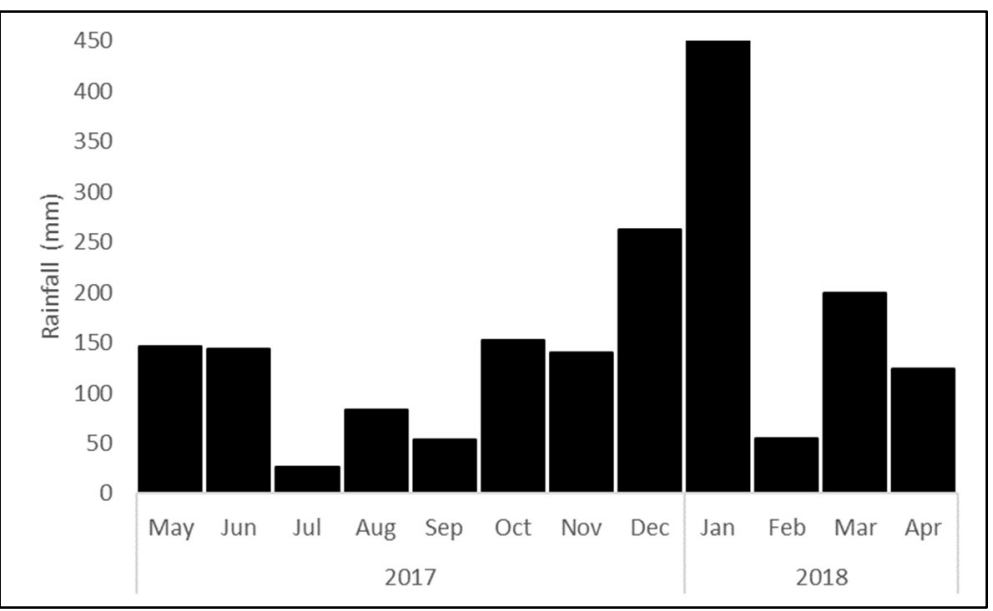

Figure 6: Monthly precipitation from SIMEPAR weather station for the study period (May 2017 - April 2018).

The annual precipitation during the study period was $1839.65 \mathrm{~mm}$. According to figure 6 , the driest month was July, with $26.2 \mathrm{~mm}$ of precipitation, and the wettest month was January, with $451.8 \mathrm{~mm}$.

\section{Correlation between phenophases and meteorological variables}

Table 5 shows the correlation $(p<0.05)$ between the phenophases and the meteorological variables. Correlations with $\mathrm{p}>0.05$ were excluded from the table. In altitudinal class I, flowering did not correlate significantly with meteorological variables. In altitudinal class II, this phenophase was negatively correlated with relative humidity $(-0.48, \mathrm{p}<0.05)$.

For aborted bunches, the analysis was significant in class I with the average temperature $(0.73 \mathrm{p}$ $<0.05)$ and maximum temperature $(0.70 p<0.05)$, which occurred in January, when the phenophase obtained its highest synchronism. In class II, this phenophase was correlated with minimum temperature $(0.77 \mathrm{p}$ $<0.05)$, maximum temperature $(0.72 p<0.05)$ and average temperature $(0.72 p<0.05)$.

Table 5: Correlation $(p<0.05)$ between phenophases and meteorological variables.

\begin{tabular}{|c|c|c|c|c|c|c|}
\hline \multirow{2}{*}{ Altitudinal class } & \multirow[t]{2}{*}{ Variables } & \multicolumn{5}{|c|}{ Phenophase } \\
\hline & & $\mathbf{F I}$ & $A b$ & If & Gf & $\mathrm{Rf}$ \\
\hline \multirow[t]{5}{*}{1} & Avg $T$ & - & 0.73 & - & - & -0.70 \\
\hline & Max T & - & 0.70 & 0.59 & - & -0.75 \\
\hline & Min T & - & - & 0.65 & - & -0.70 \\
\hline & Avg UR & - & - & - & - & - \\
\hline & Precipitation & - & - & 0.65 & - & - \\
\hline \multirow[t]{5}{*}{ II } & Avg T & - & 0.72 & - & - & -0.74 \\
\hline & $\operatorname{Max} T$ & - & 0.72 & - & - & -0.74 \\
\hline & Min T & - & 0.77 & - & - & -0.74 \\
\hline & Avg UR & -0.48 & - & - & - & - \\
\hline & Precipitation & - & - & - & - & - \\
\hline
\end{tabular}

Note: Avg - average; Max - maximum; Min - minimum; FI - flowering; Ab - aborted bunches; If - immature fruits; Gf green fruits; $\mathrm{Rf}$ - ripe fruits.

In class I, immature fruits had a significant correlation with maximum temperature $(0.58 p<0.05)$, minimum temperature $(0.65 p<0.05)$ and precipitation $(0.65 p<0.05)$. For green fruits, the correlations were 
not significant with any of the meteorological variables. Ripe fruits had negative correlations with the average temperature, maximum temperature and minimum temperature for both class I and class II, indicating that the lower the temperature, the higher the occurrence of ripe fruits in the environment.

\section{DISCUSSION}

The purpose of this research was to characterize the reproductive phenophases of E. edulis in two altitudinal classes: class I (20 to $100 \mathrm{~m}$ ) and class II (200 to $400 \mathrm{~m}$ ). For this, the activity and intensity indexes were observed and then a circular statistic and a correlation with the meteorological variables were performed for five reproductive phenophases: flowering, aborted bunches, immature fruits, green fruits and ripe fruits.

The ripe fruit phenophase presented the most interesting results regarding its difference according to the altitudinal class. In class I, ripe fruits were available from February to November, totalizing 10 of the 12 months of study, while in class II this phenophase was observed only for four months. The result found in class I corroborates Silva et al. (2018), who verified the availability of ripe fruits from March to December, in the first year of a study on the reproductive phenology and fruit production of $E$. edulis in a montane dense Ombrophilous forest. However, in the second year, they observed mature fruits for six months, indicating that the species may have years of smaller and greater activity.

In class I, during these 10 months of observation of ripe fruits, the highest synchrony was $44 \%$ (low synchrony), from May to June. This result does not corroborate Garcia et al. (2016), who observed asynchrony in this phenophase in a study conducted at a similar altitude and vegetation conditions. In class II, this phenophase showed no synchrony. Castro et al. (2007) also reported that the synchrony of mature fruits differed with altitude, studying the reproductive phenology of E. edulis on the coast of São Paulo state. For Calvi et al. (2005), the asynchronous supply of ripe fruits positively affects the feeding of the fauna, providing fruits for a longer period in the environment.

Another important factor regarding ripe fruits was that, in class II, the observation of this phenophase began in May, while in class I the phenophase was already present since February. This may cause some more specialized dispersers to move altitudinally in search of $E$. edulis fruits. For the plant, this displacement of dispersers may be interesting, as they will disperse the fruits in different places increasing $E$. edulis genetic diversity.

The period of highest intensity of ripe fruits was April, May and July, for class I, and July, for class II, corresponding to the period of lower temperatures in the Salto Morato Nature Reserve. In both altitudinal classes, ripe fruits had negative correlations with the average temperature, maximum temperature and minimum temperatures. This result indicates that the lower the temperature, the higher the occurrence of ripe fruits. The period of lower temperatures is a period of scarce food resources in the forest, according to Garcia et al. (2016), which reinforces the importance of fruiting of $E$. edulis to supply the need for food for the fauna.

In short, the results that highlights the importance of Euterpe edulis as a food source for the local 
fauna are the long fruiting period in class I; the low synchrony in class I and the asynchrony in class II; the delay of class II ripe fruits in relation to class I; and the period when ripe fruits were more intense (colder months with fewer food resources). The fact that $E$. edulis is an important food source for the local fauna is one of the reasons why it is classified as a key species in the Atlantic Forest of Brazil.

Regarding flowering phenophase, Castro et al. (2007) reported that it showed high synchrony, with activity peaks of $94 \%$ in the lowland and $86 \%$ for the premontane forest. As in the study mentioned, the month of the highest peak activity observed in the Salto Morato Nature Reserve was also in December. However, the highest synchrony value found was $44 \%$ (low synchrony) in class I. Garcia et al. (2016) described a similar result as they also observed low synchrony in flowering phenophase.

Calvi et al. (2005), in a phenological study of $E$. edulis at altitudes from 900 to $1000 \mathrm{~m}$ in Rio de Janeiro state, found no synchrony for flowering phenophase and the peak activity of this phenophase was observed in June, approximately six months after studies at lower altitudes. Despite the high synchrony found by Castro et al. (2007) in the first year of study, flowering synchrony was low in two of the three study areas in the second year, and increased again in the third year. This indicates that E. edulis may present variations of synchronism from one cycle to another for flowering, as occurred with fruiting.

Comparing the months of peak activity with peak intensity, only the peaks of aborted bunch phenophase in class I and the peaks of flowering and aborted bunch phenophases in class II occurred at the same time. It is normal for the peaks not to occur at the same because, according to Bencke et al. (2002), the activity index represents the number of individuals manifesting the phenophase at the same time, while the intensity index represents how intense the phenophase was, regardless of amount of individuals.

The average date, which indicates the day around which the phenophase is concentrated, presented a class II delay in relation to class I. Castro et al. (2007) observed a similar behavior. This difference, as well as the delay of a few months for the class II phenophases, can be explained by the presence of the adiabatic gradient, which causes the temperature to decrease with an increasing attitude.

A difference of $0.8^{\circ} \mathrm{C}$ in average temperature was found comparing the altitudinal classe I and II. Although class II temperatures were generally lower than those of class I, in the first four months of study (May, June, July and August) the average monthly minimum temperatures were higher in class I. This period correspond to the winter months in the study region, which suffer thermal inversions, according to Pajewski et al. (2018), causing the temperature in the valleys to remain colder for a longer period.

In both altitudinal classes, the aborted bunches occurred shortly after flowering and obtained positive correlations with temperature. Despite the fact that this phenophase did not have a significant correlation with precipitation, it occurred in the months of greatest precipitation, indicating that possibly a heavy rain could cause the flowers to fall and the impossibility of generating fruits. Silva et al. (2018) found a negative correlation between aborted bunches and mothers trees that presented more infructescences. According to what Silva et al. (2018) have found, aborted bunches could be related to the vigor of individuals or the fact that some individuals of this species produce only male flowers.

As in Castro et al. (2007), immature fruits were positively correlated with minimum, maximum 
temperature and precipitation. Unlike the work mentioned above, in this work no significant correlations of green fruits with meteorological variables were found. Possibly, the development of green fruits was only a consequence of immature fruits, or for some unmeasured factor.

\section{CONCLUSIONS}

With the study of the reproductive phenology of Euterpe edulis, it can be concluded that the reproductive phenophases generally manifested first in the altitudinal class I (20 to $100 \mathrm{~m}$ ) and later in the altitudinal class II (200 to $400 \mathrm{~m}$ ). Also, phenophases were available longer in altitudinal class I. The delay in the presence or absence of phenophases in individuals of the second class in relation to the first is due to the occurrence of the adiabatic gradient. Long-term monitoring will allow a better understanding of the phenology of Euterpe edulis. With this, it will be possible to elaborate management and conservation plans of the species in the Salto Morato Nature Reserve.

ACKNOWLEDGEMENTS: This study was financed by the CAPES - Coordenação de Aperfeiçoamento de Pessoal de Nível Superior - Brazil (Coordination of Superior Level Staff Improvement), finance code 001, and by Boticário Group Fondation.

\section{REFERENCES}

ALVARES, C. A.; STAPE, J. L.; SENTELHAS, P. C.; GONÇALVES, J. L. M.; SPAROVEK, G.. Köppen's climate classification map for Brazil. Meteorologische Zeitschrift, Stuttgart, v.22, p.711-728, 2013. DOI: http://doi.org./10.1127/0941$\underline{2948 / 2013 / 0507}$

BENCKE, C. S. C.; MORELLATO, L. P. C.. Comparação de dois métodos de avaliação da fenologia de plantas, sua interpretação e representação. Brazilian Journal of Botany, São Paulo, v.25, n.3, p.269-275, 2002. DOI: http://doi.org./10.1590/S0100-84042002000300003

BGF. Boticário Group Foundation. Plano de manejo da Reserva Natural Salto Morato/Guaraqueçaba. Curitiba: BGF, 2011.

BRAZIL. Brazilian Ministry Of The Environment. Ordinance number 443, Section 1, Number 245, December 18th, 2014. Brasília: DOU, 2014.

CALVI, G. P.; PIÑA-RODRIGUES, F. C. M.. Fenologia e reprodução de sementes de Euterpe edulis Mart. em trecho de floresta de altitude no município de Miguel Pereira - RJ. Revista de Ciências da Vida, v.25, n.1, p.33-40, 2005.

CARVALHO, C. S.; BALLESTEROS-MEJIA, L.; RIBEIRO, M. C.; CÔRTES, M. C.; SANTOS, A. S.; COLLEVATTI, R. G.. Climatic stability and contemporary human impacts affect the genetic diversity and conservation status of a tropical palm in the Atlantic forest of Brazil. Conservation Genetics, v.18, p.467-478, 2017. DOI: http://doi.org./10.1007/s10592-016$\underline{0921-7}$

CASTRO E. R.; GALETTI, M.; MORELLATO, L. P. C..

Reproductive phenology of Euterpe edulis (Arecaceae) along a gradient in the Atlantic rainforest of Brazil. Australian Journal of Botany, v.55, n.7, p.725-735, 2007. DOI: http://doi.org./10.1071/BT07029

FOURNIER, L. A.; CHARPANTIER, C.. El tamaño de la muestra y la frecuencia de las observaciones en el estudio de las características fenológicas de las árboles tropicales. Turrialba, v.25, n.1, p.45-48, 1975.

FRITZSONS, E.; MANTOVANI, L. E.; WREGE, M. S.. Relação entre altitude e temperatura: uma contribuição ao zoneamento climático no estado de Santa Catarina, Brasil. Revista Brasileira de Climatologia, v.18, p.80-92, 2016. DOI: http://doi.org./10.5380/abclima.v18i0.39471

GALETTI, M.; GUEVARA, R.; CÔRTES, M. C.; FADINI, R.; VON MATTER, S.; LEITE, A. B.; LABECCA, F.; RIBEIRO, T.; CARVALHO, C. S.; COLLEVATTI, R. G.; PIRES, M. M.; GUIMARÃES JÚNIOR, P. R.; BRANCALION, P. H.; RIBEIRO, M. C.; JORDANO, P.. Functional extinction of birds drives rapid evolutionary changes in seed size. Science, v.340, p.10861090, 2013. DOI: http://doi.org./10.1126/science.1233774

GALETTI, M.; ZIPPARRO, V.; MORELLATO, L. P.. Fruit phenology and frugivory on the palm Euterpe edulis in a lowland atlantic forest of Brazil. Ecotropica, v.5, p.115-122, 1999.

GARCIA, V. A.; BARBEDO, C. J.. Estudo fenológico de Bactris gasipaes Kunth, Euterpe edulis Mart. e Syagrus romanzoffiana (Cham.) Glassman no Vale do Ribeira, SP, Brasil. Hoehnea, v.43, n.1, p.135-149, 2016. DOI: http://doi.org./10.1590/2236-8906-40/2015

LIETH, H.. Introduction to phenology and the modeling of 
seasonality. In: LIETH, H.. Phenology and seasonality modeling. New York: Springer, 1974. p.3-19.

MANTOVANI, A.; MORELLATO, P.. Fenologia da floração, frutificação, mudança foliar e aspectos da biologia floral. In: REIS, M. S.; REIS, A.. Euterpe edulis Martius - (Palmiteiro): biologia, conservação e manejo. Itajaí: Herbário Barbosa Rodrigues, 2000. p.23-38.

MARTINELLI, G.; MORAES, M. A.. Livro vermelho da flora do Brasil. Rio de Janeiro: Rio de Janeiro Botanic Garden Research Institute, 2013.

MILANI, J. E. F.. Comportamento fenológico de espécies arbóreas em um fragmento de floresta ombrófila mista aluvial - Araucária, PR. Dissertation (Master in Forest Engineering) - Federal University of Paraná, Curitiba, 2013.

MULER, A. E.; ROTHER, D. C.; BRANCALION, P. S.; NAVES, R. P.; RODRIGUES, R. R.; PIZO, M. A.. Can overharvesting of a non-timber-forest-product change the regeneration dynamics of a tropical rainforest? The case study of Euterpe edulis. Forest Ecology and Management, v.324, p.117-125, 2014. DOI: https://doi.org/10.1016/j.foreco.2013.09.001

PAJEWSKI, F. F.; TETTO, A. F.; BEHLING, A.; MILANI, J. H. F.; TRES, A.. Efeito da altitude sobre as variáveis meteorológicas em um trecho de Floresta Ombrófila Densa Submontana. Biofix Scientific Journal, v.3, n.2, p.302-310, 2018. DOI: https://doi.org/10.5380/biofix.v3i2.61130

SILVA, J. Z.; REIS, M. S.. Fenologia reprodutiva e produção de frutos em Euterpe edulis (Martius). Ciência Florestal, v.28, n.1, p.295-309, 2018. DOI: https://doi.org/10.5902/1980509831655

WMO. World Meteorological Organization. Guide to meteorological instruments and methods of observation. 2018 edition. Geneva: Chairperson, 2018.

A CBPC - Companhia Brasileira de Produção Científica (CNPJ: 11.221.422/0001-03) detém os direitos materiais desta publicação. Os direitos referem-se à publicação do trabalho em qualquer parte do mundo, incluindo os direitos às renovações, expansões e disseminações da contribuição, bem como outros direitos subsidiários. Todos os trabalhos publicados eletronicamente poderão posteriormente ser publicados em coletâneas impressas sob coordenação da Sustenere Publishing, da Companhia Brasileira de Produção Científica e seus parceiros autorizados. Os (as) autores (as) preservam os direitos autorais, mas não têm permissão para a publicação da contribuição em outro meio, impresso ou digital, em português ou em tradução. 